\title{
Distribution of leptocephali in the Kuroshio Current and East China Sea
}

\author{
Michael J. Miller ${ }^{1, *}$, Tsuguo Otake ${ }^{2}$, Gen Minagawa ${ }^{1}$, Tadashi Inagaki ${ }^{1}$, \\ Katsumi Tsukamoto ${ }^{1}$
}

${ }^{1}$ Ocean Research Institute, The University of Tokyo, Minamidai, Nakano, Tokyo 164-8639, Japan

${ }^{2}$ Faculty of Bioresources, Mie University, Kamihama, Tsu 514-8507, Japan

\begin{abstract}
A first-of-its-kind sampling survey using a large midwater plankton net appropriate for collecting leptocephali was carried out in transects across the shelf break at the edge of the Kuroshio Current and East China Sea and in the western North Pacific Ocean south of the Ryukyu Islands during late November and early December. Leptocephali of at least 45 species of 10 families of anguilliform eels were collected. Catch rates and the species richness of leptocephali were higher in the Kuroshio region than in the western Pacific Ocean. The most abundant leptocephali in the region were of the eel families Congridae, Synaphobranchidae, Ophichthidae, Muraenidae and Nettastomatidae. Several taxa of congrid eels, including Gnathophis nystromi nystromi and Ariosoma spp., were spawning along the edge of the Kuroshio Current, as were muraenids, ophichthids, nettastomatids and Dysomma anguillare (Synaphobranchidae). The 2 most abundant species, G. nystromi nystromi and D. anguillare, appeared to be spawning near the edge of the shelf break in the central Kuroshio region, but the spawning of Ariosoma spp. and several other species was centered farther south to the northeast of Taiwan. This is the first discovery of the spawning of eels along a shelf break adjacent to a major western boundary current, and spawning in this region would result in their leptocephali having the potential for being transported to a wide range of areas by the Kuroshio and Tsushima Warm Currents.
\end{abstract}

KEY WORDS: Leptocephali $\cdot$ Eels $\cdot$ Spawning area $\cdot$ Kuroshio Current $\cdot$ East China Sea Resale or republication not permitted without written consent of the publisher

\section{INTRODUCTION}

The East China Sea (ECS) is an important area for many different species of commercial fishes including several species of marine eels of the order Anguilliformes (Okamura 1986). Conger myriaster, C. japonicus, Murenosox cinereus, M. bagio and Ariosoma meeki are harvested from the ECS and from coastal areas of Japan, and a variety of other marine eels of the families Congridae, Muraenidae, Ophichthidae, Nettastomatidae and Synaphobranchidae are found in the shallow areas of the continental shelf throughout the region (Masuda et al. 1984, Okamura 1986, Nakabo 2000). Almost nothing is known about the spawning

\footnotetext{
*E-mail: miller@ori.u-tokyo.ac.jp
}

ecology and life history of eel species in the region, except for the catadromous Japanese eel Anguilla japonica, which spawns in the North Equatorial Current region of the western North Pacific to the west of the Mariana Islands (Tsukamoto 1992). The larvae of A. japonica drift westward and then enter the base of the Kuroshio Current, which transports them into the ECS region where they recruit to Taiwan, Japan, Korea, and eastern China.

The larvae of eels are called leptocephali, and they have laterally compressed, transparent bodies and increase much more in size and have a longer larval duration before metamorphosis than most fish larvae (Smith 1989a). This longer larval duration makes the spawning location of eels in relation to the location of their juvenile and adult habitats and to the patterns of ocean currents in the region very important, because 
of the potential for long-distance transport of their larvae. Studies on leptocephali are often one of the best ways to learn about the reproductive ecology and life history of eels, which are usually difficult to observe or collect. This is true for anguillid eels, whose oceanic spawning habits are only known based on the distribution of their leptocephali (Schmidt 1922, Jespersen 1942, Tsukamoto 1992, McCleave 1993, Aoyama et al. 1999) or studies of their otolith microstructure (Tsukamoto et al. 1998, Arai et al. 2001).

Studies of the leptocephali of marine eels also can provide valuable new information about the spawning areas and general species composition of eels in regions such as the shelf areas of the ECS. There has been some research on the leptocephali of marine eel families in the western Pacific (Castle 1965, 1997, Castle \& Robertson 1974, Mochioka et al. 1982, 1988, 1991, Lee \& Byun 1996), and in the western North Atlantic (Castle 1970, 1979, Castonguay \& McCleave 1987a, Miller \& McCleave 1994, Miller 1995, Smith \& Miller 1996, Wippelhauser et al. 1996), but not much is known about the leptocephali or the spawning areas of marine eels throughout the western Pacific.

The objectives of this study were to describe the species composition, distribution, relative abundance, and size of leptocephali in the western North Pacific and ECS region to determine the spawning locations of congrid and other species of marine eels along the boundary of the Kuroshio Current and ECS. Sampling for leptocephali took place during a cruise of the RV 'Tansei Maru' in the western North Pacific Ocean south of the Ryukyu Islands and along transects that extended from within the Kuroshio Current over the deep water of the Okinawa Trench to the shelf in the shallow waters of the ECS. This is the only study that has sampled leptocephali across a shelf break along a major western boundary current, and it provides the opportunity to learn about the spawning locations and distributional ecology of the leptocephali of the marine eels that live on the continental shelf of the ECS.

\section{MATERIALS AND METHODS}

Study area. The Kuroshio Current is the major western boundary current of the North Pacific Ocean gyre and is formed at the western end of the North Equatorial Current (NEC) along the northeastern edge of the
Philippines (Nitani 1972). The northern part of the westward flow of the NEC turns north, flows past the east side of Taiwan, and then turns northeast, becoming the Kuroshio Current. The southern part of the NEC turns south and forms the Mindanao Current, which flows along the east side of the southern Philippines (Lukas et al. 1991). The Kuroshio then flows to the northeast, over the Okinawa Trench (>2000 m deep) on the west of the Ryukyu Islands (Fig. 1). In this area it flows adjacent to the shelf break along the eastern edge of the ECS, which is located over the large area of continental shelf between Taiwan, eastern China, southern Korea and southern Japan. The average location of the front at the western edge of the

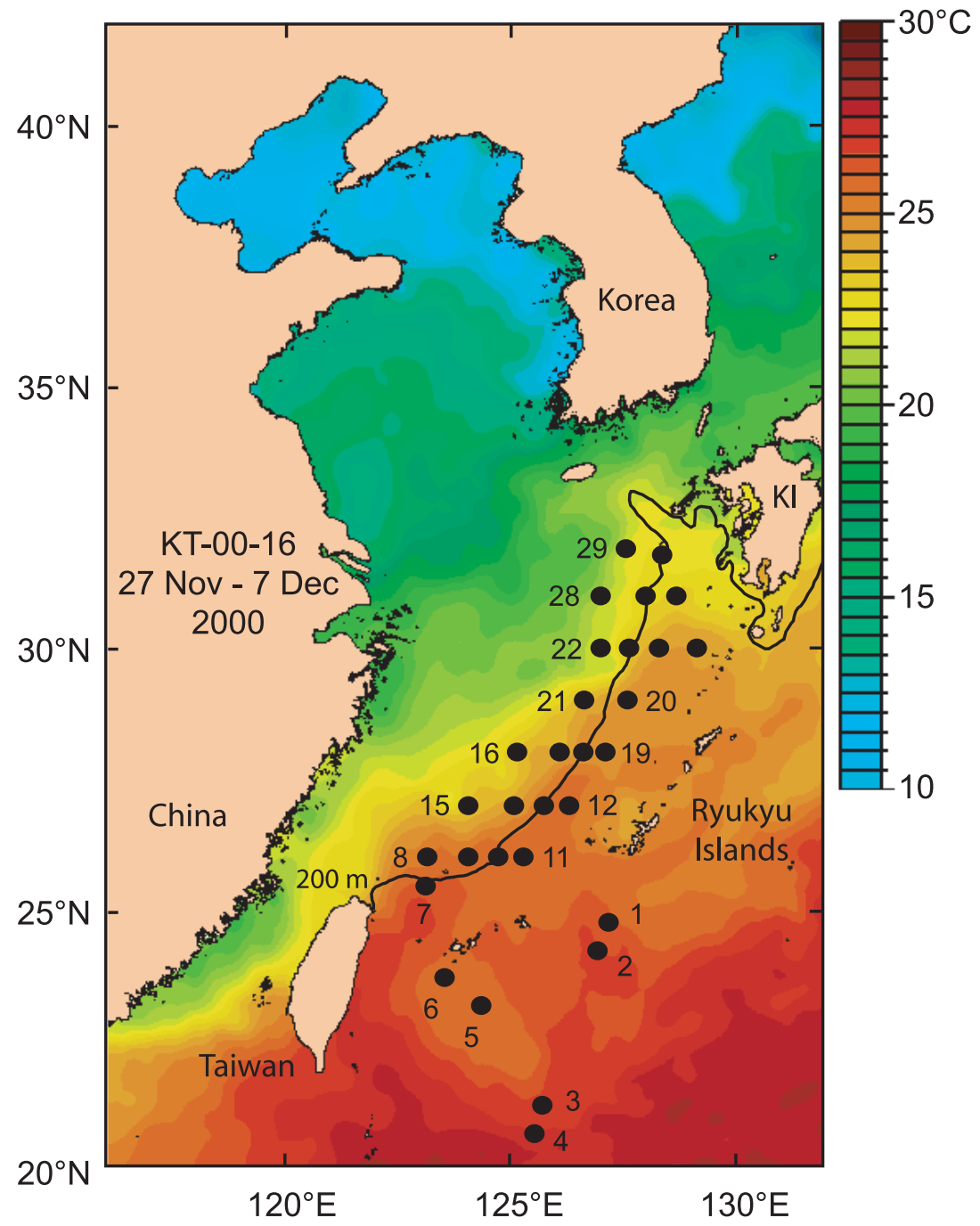

Fig. 1. Map of study area showing approximate sea surface temperature (SST) on 30 November 2000, the location of the sampling stations ( $\bullet$ ), the station numbers of some stations to indicate the sequence of sampling, and $200 \mathrm{~m}$ depth contour along the boundary of the Kuroshio Current and East China Sea. SST map was obtained from the Naval Research Laboratory (USA). KI: Kyushu Island, southernmost main island of Japan 
Kuroshio corresponds approximately to the $200 \mathrm{~m}$ depth contour at the edge of the continental shelf from about 26 to $29^{\circ} \mathrm{N}$ (Qiu et al. 1990). The Kuroshio then turns to the east just south of Kyushu Island, which is the southernmost large island of Japan. The highvelocity region of the Kuroshio is located up against the shelf break, extends down to about $500 \mathrm{~m}$, and is about $150 \mathrm{~km}$ wide from about 25 to $30^{\circ} \mathrm{N}$ in the fall (Yuan et al. 1994, Kaneko et al. 1990). These observations correspond to the flow of the Kuroshio that was indicated by Doppler current profiler data collected during the cruise ( $T$. Inagaki unpubl. data), but the location of the western edge of the Kuroshio varies to some extent between seasons and as a result of meanders (Qiu et al. 1990, Chen et al. 1992, Hwang 1996).

Sampling took place on both the warm and cold sides of the Kuroshio front during the cruise. The difference in surface water temperature between the easternmost stations in the Kuroshio and the westernmost stations in the colder water over the shelf in the longer transects ranged from 2.1 to $3.7^{\circ} \mathrm{C}$, with an overall range between 21.0 and $26.3^{\circ} \mathrm{C}$ in the Kuroshio region (Fig. 1). The Kuroshio Current may sometimes extend a short distance to the west over the shelf in the central portion of the ECS (Kaneko et al. 1990), but other flows to the northeast have been observed farther west over the shelf during summer, and have been termed the Kuroshio Branch and the Taiwan Current (Katoh et al. 2000).

In the northern part of the study area, the main part of the Kuroshio turns sharply to the east just to the south of Kyushu Island and then flows to the northeast along southeastern Japan (Qiu et al. 1990, Hsueh et al. 1996, Qiu \& Miao 2000). Part of the western edge of the flow of the Kuroshio to the south of Kyushu Island appears to separate and turn to the north, forming the Tsushima Warm Current (Lie \& Cho 1994, Lie et al. 1998, Katoh et al. 2000). This current then flows through the Tsushima Strait, which is between the southern end of the Korean Peninsula and the northwest side of Kyushu Island (Fig. 1). The Doppler current profiler data indicated that Stn 29 (the northwesternmost station of the cruise) was probably located within the northwest flow of the Tsushima Warm Current, and that all the stations to the south of $30^{\circ} \mathrm{N}$ that were at or to the east of the $200 \mathrm{~m}$ depth contour were within the Kuroshio Current (T. Inagaki unpubl. data).

Methods. Sampling for leptocephali was carried out during the KT-00-16 cruise of the RV 'Tansei Maru' of the Ocean Research Institute, The University of Tokyo, from 27 November to 7 December 2000. Leptocephali were collected with $3 \mathrm{~m}$ Isaacs Kidd midwater trawls (IKMT) that had $8.7 \mathrm{~m}^{2}$ mouth openings and either 1.0 or $0.5 \mathrm{~mm}$ mesh. The IKMT were fished using both oblique tows from the surface to $300 \mathrm{~m}$ or to within $20 \mathrm{~m}$ of the bottom, and in horizontal step tows within the upper $150 \mathrm{~m}$ that targeted the strongest scattering layer observed using hydroacoustics. The amount of water filtered by each tow was determined using a flow meter. Collections were made in single tows at 5 stations between $20-25^{\circ} \mathrm{N}$ and $123-127^{\circ} \mathrm{E}$ to the south of the Ryukyu Islands, and in 50 tows at 24 stations in the Kuroshio Current region between Taiwan and Kyushu Island (Fig. 1). Single oblique tows were made at night at 6 stations in the western North Pacific (WNP) region, but the sample at Stn 5 was lost due to damage to the cod end, presumably by a pelagic shark. In the Kuroshio region, both an oblique and step tow was made at all but 2 stations (one with just an oblique and another with an additional step tow) during both night and day.

Conductivity, temperature, depth profiles (CTD) were made at 23 of the 29 stations, depending on the sea state at the time. The sea surface temperatures (SST) measured at each station during the cruise typically differed by less than $\sim 0.5^{\circ} \mathrm{C}$ from those in Fig. 1 , but differences of up to $\sim 1.0^{\circ} \mathrm{C}$ were measured at a few stations over the shelf, resulting from small-scale eddy features or movements of the Kuroshio front, which could certainly have changed to some degree as the cruise continued beyond the 30 November date (Stns 6-9) of the SST map.

Leptocephali were sorted fresh from the plankton, measured to the nearest $0.1 \mathrm{~mm}$ total length (TL), and identified according to Tabeta \& Mochioka (1988). (The details of species identification of the leptocephali of most taxa will not be discussed in this paper.) The leptocephali were then either preserved in a $10 \%$ formalin-seawater solution or in $95 \%$ ethanol. Although the majority of specimens was identified and measured fresh on board the ship, some were measured in the laboratory after fixation in formalin and these lengths were subsequently adjusted using the shrinkage regression equation $\left(y=-0.25+1.03 x, r^{2}=0.99\right)$ generated from 40 specimens measured before and after fixation in formalin.

\section{RESULTS}

\section{Species composition of leptocephali}

Leptocephali of at least 46 species of anguilliform eels were collected during the cruise, but $93 \%$ of the specimens belonged to 4 of the 10 families represented in the collections. Congridae was the most abundant family, with 11 or more species collected in the Kuroshio Current region during the cruise. Gnathophis nystromi nystromi was by far the most abundant congrid, and was the most abundant species during the cruise: 976 leptocephali were collected that appeared 
to belong to this species. There were at least 5 species of Ariosoma (Species 3 to 7 of Tabeta \& Mochioka 1988), 3 species of Congrinae (2 types with 1 row of lateral pigment that corresponded with the vertebral ranges of Bathycongrus baranesi and Uroconger lepturus [Nakabo 2000] and 1 type with 4 rows of lateral pigment), and 1 species of Gorgasia (possibly G. taiwanenis), which is one of the 2 genera of garden eels (Castle 1997). Leptocephali that appeared to be predominantly Conger japonicus (142 to 145 vertebrae) were collected, but $C$. cinereus (138 to 145 ) has a similar range of vertebrae, so definitive identification using genetic analysis needs to be done, since $C$. cinereus is found in the Ryukyu Islands and $C$. japonicus in southern Japan and the Korean Peninsula (Nakabo 2000).

The other abundant leptocephali in the region were of the eel families Synaphobranchidae, Ophichthidae, Muraenidae and Nettastomatidae (Table 1). The synaphobranchid Dysomma anguillare (subfamily Ilyophinae) was the second most abundant species during the cruise $(\mathrm{N}=593)$, but leptocephali of the Synaphobranchinae were much less abundant. Ophichthidae was the third most abundant family, with at least 1 specimen of $\geq 17$ species in 2 subfamilies collected in the Kuroshio region (Table 1). Ophichthinae Species 3 of Tabeta \& Mochioka (1988) was by far the most abundant ophichthid ( $\mathrm{N}=$ 187) collected during the study. The Muraenidae was the next most abundant family, with at least 7 species collected in the study area (possibly many more were present, but unidentifiable due to the limited characters that can be used to separate their leptocephali; see Smith 1989b). Leptocephali of at least 3 species of nettastomatids also were collected in the Kuroshio region, including 2 specimens of Nettenchlys gephyra and a large number of leptocephali that appeared to be either Saurenchlys lateromaculatus or S. stylurus, which have overlapping ranges of myomeres (Tabeta \& Mochioka 1988).

A variety of other species of 7 families were collected in relatively low abundances during the cruise. Leptocephali of the shelf families Chlopsidae and Moringuidae were rare, as were the oceanic families of Nemichthyidae and Serrivomeridae (Table 1). No more than 2 species of each of these families were collected during the cruise. Nine specimens of Anguilla japonica also were collected, but these will be described in detail elsewhere. In addition to the 11 families of anguilliform eels, a few specimens of the Elopiformes $(\mathrm{N}=10)$ and Saccopharyngiformes $(\mathrm{N}=1)$ were collected.

\section{Size range and development stage}

The leptocephali of different species of eels typically reach a variety of maximum lengths, ranging from about 40 to $300 \mathrm{~mm}$ TL (see Böhlke 1989), and individuals with total lengths throughout the size range of many of the taxa were collected during the cruise (Figs. 2 \& 3). How-

Table 1. Number of leptocephali of each taxa and range of total length (TL) of the leptocephali collected during the KT-00-16 cruise in the western North Pacific (WNP) and in the Kuroshio Current region. The type of life history of each taxon based on what type of habitat is used by its juveniles and adults is indicated. CT: catadromous (entering freshwater), SH: continental shelf or shallow marine habitats; OC: open-ocean meso- or bathypelagic habitats; SL: slope or deep benthic habitats. Minimum number of species of each family in parentheses

\begin{tabular}{|c|c|c|c|c|c|}
\hline Taxon & $\begin{array}{c}\text { Life } \\
\text { history }\end{array}$ & WNP & Kuroshio & Total & $\begin{array}{l}\text { TL range } \\
\text { (mm) }\end{array}$ \\
\hline \multicolumn{6}{|l|}{ Anguillidae (1) } \\
\hline Anguilla japonica & $\mathrm{CT}$ & & 9 & 9 & $51.3-57.0$ \\
\hline \multicolumn{6}{|l|}{ Congridae (11) } \\
\hline Ariosoma spp. & $\mathrm{SH}$ & 5 & 27 & 32 & $6.0-239.0$ \\
\hline Ariosoma sp.3 & $\mathrm{SH}$ & 1 & & 1 & 157.2 \\
\hline Ariosoma sp.4 & $\mathrm{SH}$ & & 1 & 1 & 36.8 \\
\hline Ariosoma sp.5 & $\mathrm{SH}$ & 4 & 14 & 18 & $22.3-167.0$ \\
\hline Ariosoma sp.6 & $\mathrm{SH}$ & 1 & 3 & 4 & $20.2-202.0$ \\
\hline Ariosoma sp.7 & $\mathrm{SH}$ & 4 & 6 & 10 & $40-147.5$ \\
\hline Conger sp. & $\mathrm{SH}$ & 6 & 61 & 67 & $9.4-74.0$ \\
\hline Congrinae spp. & SH & 2 & 83 & 85 & $9.4-151.8$ \\
\hline Gnathophis nystromi nystromi & i $\mathrm{SH}$ & 20 & 956 & 976 & $6.8-88.8$ \\
\hline Gorgasia sp. & $\mathrm{SH}$ & & 1 & 1 & 28.1 \\
\hline Chlopsidae (2) & $\mathrm{SH}$ & 2 & & 2 & $55.2-76.8$ \\
\hline \multicolumn{6}{|l|}{ Moringuidae (1) } \\
\hline Moringua sp. & $\mathrm{SH}$ & & 3 & 3 & $16.2-30.0$ \\
\hline Muraenidae (7) & $\mathrm{SH}$ & 2 & 109 & 111 & $9.4-76.1$ \\
\hline \multicolumn{6}{|l|}{ Nemichthyidae (2) } \\
\hline Nemichthys sp. & $\mathrm{OC}$ & 5 & 2 & 7 & $42.4-158.0$ \\
\hline Nemichthys scolopaceus & $\mathrm{OC}$ & 2 & 17 & 19 & $18.4-55.6$ \\
\hline Nettastomatidae (3) & $\mathrm{SH}$ & & 100 & 100 & $10.0-63.8$ \\
\hline \multicolumn{6}{|l|}{ Ophichthidae (17) } \\
\hline Myrophinae spp. & $\mathrm{SH}$ & & 23 & 23 & $11.5-61.9$ \\
\hline Ophichthinae spp. & $\mathrm{SH}$ & & 257 & 257 & $8.4-82.5$ \\
\hline Serrivomeridae (1) & $\mathrm{OC}$ & 1 & 5 & 6 & $7.8-33.2$ \\
\hline \multicolumn{6}{|l|}{ Synaphobranchidae (2) } \\
\hline Dysomma anquillare & SH & & 593 & 593 & $7.9-43.0$ \\
\hline Synaphobranchinae sp. & SL & 11 & 15 & 26 & $10.6-30.5$ \\
\hline Elopiformes (2) & $\mathrm{SH}$ & 1 & 9 & 10 & $9.5-59.0$ \\
\hline \multicolumn{6}{|l|}{ Saccopharyngiformes (1) } \\
\hline Eurypharynx pelecanoides & $\mathrm{OC}$ & & 1 & 1 & 21.9 \\
\hline Other & & 4 & 13 & 17 & \\
\hline Total & & 71 & 2308 & 2379 & \\
\hline
\end{tabular}


Fig. 2 Length-frequency distributions of the most abundant taxa of leptocephali collected during the cruise
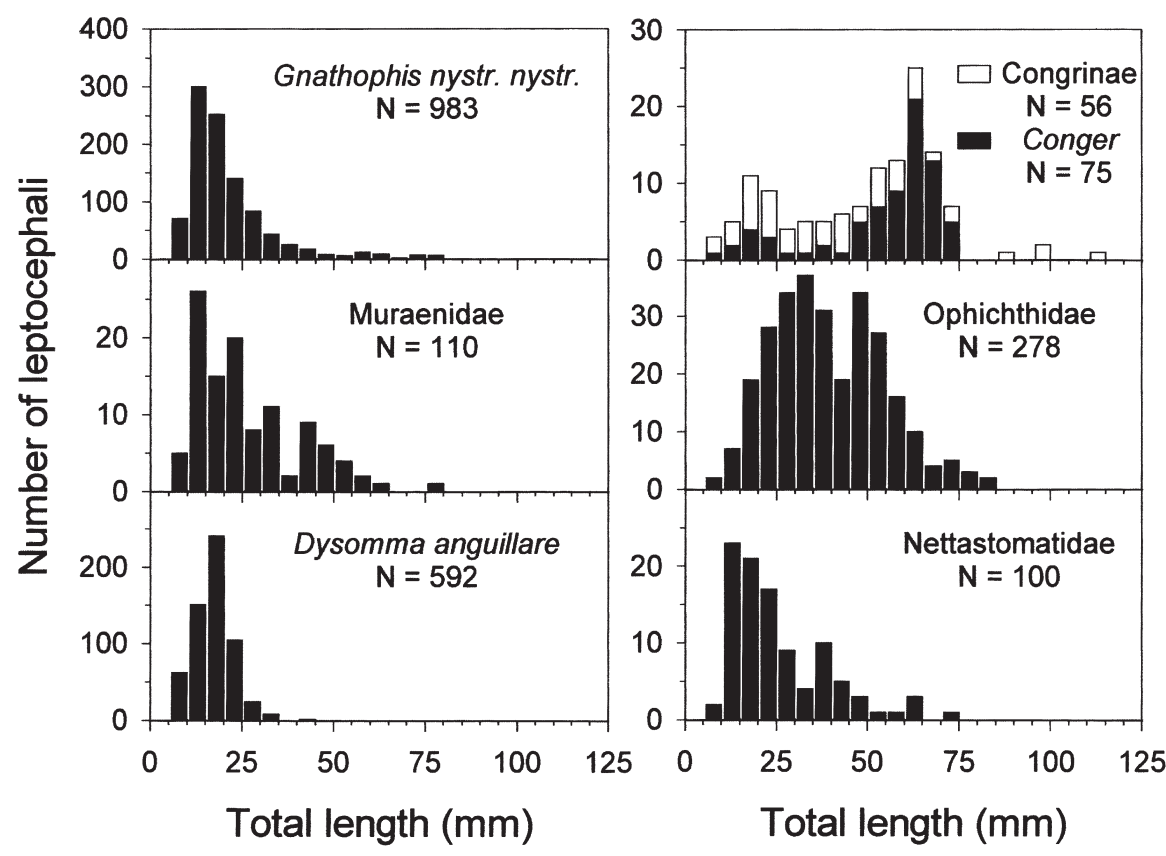

ever, the length-frequency distributions of the taxa that appeared to be spawning in the Kuroshio region, such as Gnathophis nystromi nystromi, Ariosoma spp., Congrinae, muraenids, Dysomma anguillare, ophichthids, and nettastomatids, generally showed a higher proportion of smaller individuals. Relatively recently spawned leptocephali (6 to $10 \mathrm{~mm}$ TL) of all these taxa were collected in the western Kuroshio region (Figs. 2 \& 3). Overall, there were leptocephali $\leq 10 \mathrm{~mm}$ TL of at least 11 taxa collected during the cruise. The $\leq 20 \mathrm{~mm}$ leptocephali of G. nystromi nystromi and D. anguillare were the most abundant, but $\leq 25 \mathrm{~mm}$ muraenids, nettastomatids and ophichthids were also relatively abundant.

Although most leptocephali were well below their maximum lengths, there were some large specimens of most taxa (Figs. 2 \& 3), as well as a small number of specimens that were undergoing metamorphosis. A few metamorphosing leptocephali of Ariosoma spp. $(\mathrm{N}=5,201$ to $239 \mathrm{~mm} \mathrm{TL})$ and large Gnathophis nystromi nystromi leptocephali ( $\mathrm{N}=20,41$ to $82 \mathrm{~mm}$ ) were collected in the WNP region (Stns 1 to 6). In the Kuroshio region there were 2 metamorphosing G. nystromi nystromi leptocephali (59 and $63 \mathrm{~mm}$ ), an early-stage metamorphosing muraenid leptocephalus (53 mm), 9 metamorphosing or early-stage glass eels of Anguilla japonica (51 to $57 \mathrm{~mm}$ ), and 1 Gnathophis sp. glass eel (53 mm) collected during the study.

\section{Distribution and abundance}

Analysis of the catch rates of leptocephali in each tow made with the IKMT within the Kuroshio region found no significant difference between oblique or step tows (Mann-Whitney $U$-test, $\mathrm{p}=0.83$ ) or among tows made during daytime, at night, around sunset, or around sunrise (Kruskal-Wallis test, $\mathrm{p}=0.81$ ) (Fig. 4). This is in contrast to collections with an IKMT in the clear, lower productivity water of the open ocean, where catches of leptocephali during the day have been found to be significantly lower than those at night (Miller \& McCleave 1994). However, the water over the continental shelf in the Kuroshio region was a darker color and showed a higher degree of biofouling of the mesh of the net during the cruise than in the WNP, so visual avoidance of the trawl (Castonguay \& McCleave 1987b) during the day may have been reduced over the shelf due to the less transparent water. Therefore, all the tows of the study were used in the analysis of catch rates and species distributions.

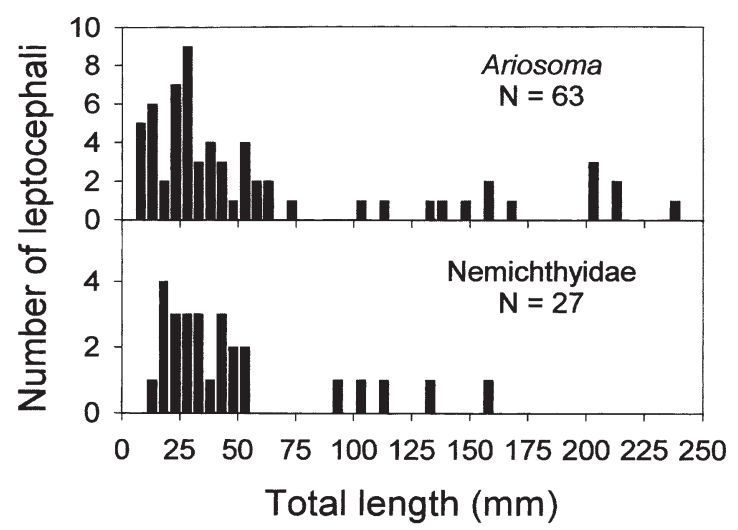

Fig. 3. Congridae (Ariosoma spp.) and Nemichthyidae (Nemichthys spp.). Length-frequency distributions of the leptocephali collected during the cruise 
Leptocephali were much more abundant in the Kuroshio Current region (at least 41 species) than in the WNP area (at least 15 species; Table 1), and many taxa showed evidence of spawning activity along the edge of the Kuroshio Current and over the shelf. Catch rates of leptocephali in the oblique night tows in the WNP were much lower and were significantly different than in the oblique night tows in the Kuroshio region (Mann-Whitney $U$-test, $\mathrm{p}=0.03$ ) (Fig. 4A).

The catch rates at the stations at or deeper than the $200 \mathrm{~m}$ depth contour ( $\mathrm{N}=30$ tows, including the stations on either side of, but touching the $200 \mathrm{~m}$ contour in Fig. 1) and the stations over the shelf $(\mathrm{N}=20)$, which had a higher average catch rate (Fig. 4C), were significantly different (Mann-Whitney $U$-test, $\mathrm{p}=0.03$ ). However, when compared based on the SST measured at each station, there was no significant difference between the catch rates at warm-water stations $(\mathrm{N}=$ $28,23.9$ to $\left.26.0^{\circ} \mathrm{C}\right)$ and cold-water stations $(\mathrm{N}=22,21.0$ to $22.8^{\circ} \mathrm{C}$ ) in the Kuroshio region (Fig. $4 \mathrm{C}$ ).

The small, recently spawned, leptocephali of many taxa were collected in the Kuroshio region, but not in the offshore areas of the WNP. The smallest specimens of some taxa of congrids were collected at the western stations in the southern Kuroshio region but, based on the distribution of its leptocephali $\leq 10 \mathrm{~mm}$ TL (Fig. 5), Gnathophis nystromi nystromi was apparently spawning somewhere near the shelf break in the central Kuroshio region. Small Dysomma anguillare leptocephali showed a different distribution that suggested they spawn over water $200 \mathrm{~m}$ or deeper in the central Kuroshio region.

Some taxa such as ophichthids, muraenids, and Congrinae species were collected at all or most of the westernmost stations of each transect, which were in shallow waters over the shelf (Fig. 5). Other taxa were present throughout most of the Kuroshio region, but at least 5 of these were absent from $\operatorname{Stn} 28\left(21.0^{\circ} \mathrm{C}\right)$, or from a few of the other cold-water stations over the shelf (Figs. 1 \& 5). Ariosoma spp. were absent from many of the westernmost stations in the Kuroshio region, but were present at all the stations in the WNP. Leptocephali of Dysomma anguillare and Nettastomatidae were collected in the 6 northern transects, but were absent from the southern transect and the WNP, as were ophichthids and all but 2 muraenid leptocephali. The oceanic taxa Nemichthyidae, Synaphobranchinae, and Serrivomeridae were present at some of the WNP stations and in the southern Kuroshio region, but only Nemichthyidae were present in the northern transects (Fig. 5). Anguilla japonica specimens were collected at 4 of the 5 eastern stations in the Kuroshio. The distribution of the leptocephali of the order Elopiformes appeared to be distributed along the shelf break at the edge of the Kuroshio Current, except for 1 specimen collected in the WNP (Fig. 5).

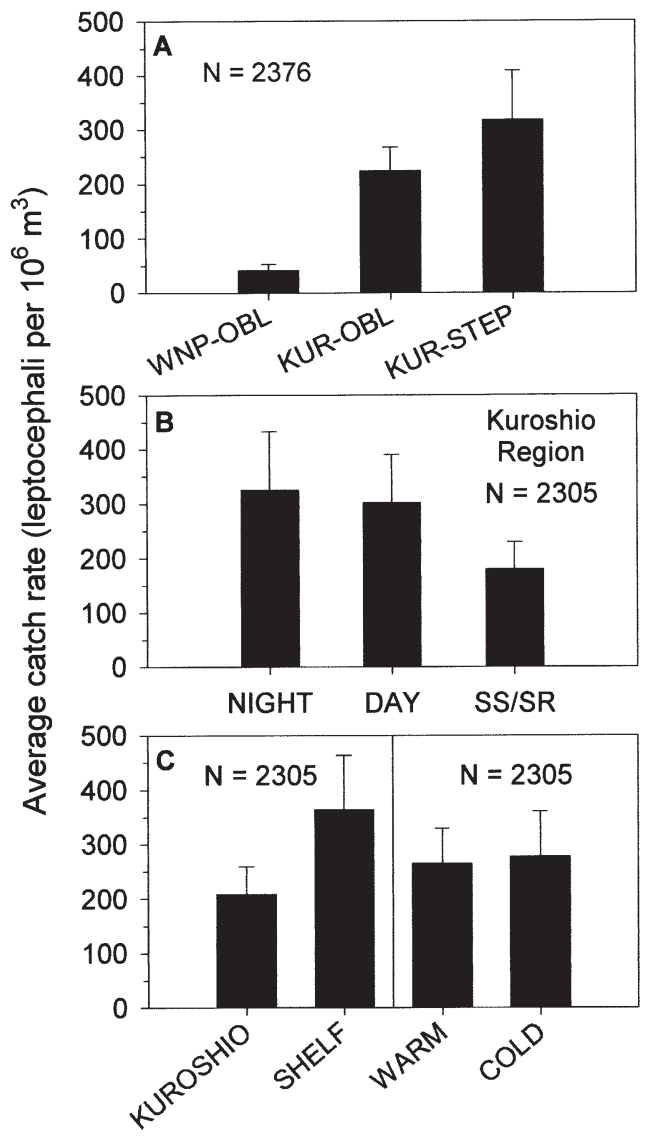

Locations, type and time of day of tows

Fig. 4 Catch rates of leptocephali of all taxa (average and standard error) expressed as number of leptocephali per amount water filtered by the trawl in (A) the western North Pacific (WNP) and Kuroshio Current region (KUR) in oblique (OBL) and step tows (STEP); (B) tows made during night, day, and sunset/sunrise (SS/SR); (C) tows made over water $\sim 200 \mathrm{~m}$ or deeper (Kuroshio) or over the shelf, and at stations with warm or cold sea surface temperature (see 'Results' for details)

\section{DISCUSSION}

\section{Species composition and relative abundance}

The assemblage of leptocephali along the Kuroshio Current was very different than the assemblage in the WNP area and was dominated by species that were spawning somewhere near the Kuroshio. The WNP had low catch rates compared to the Kuroshio region, and large-sized Ariosoma spp., Gnathophis nystromi nystromi, Congrinae, chlopsid and Nemichthys spp. leptocephali, but more than 30 species found along the Kuroshio were absent in the WNP. In contrast, large numbers of relatively small leptocephali were collected along the Kuroshio and over the shelf. There appears to be a variety of species of eels that live and probably spawn in the eastern region of the ECS, espe- 


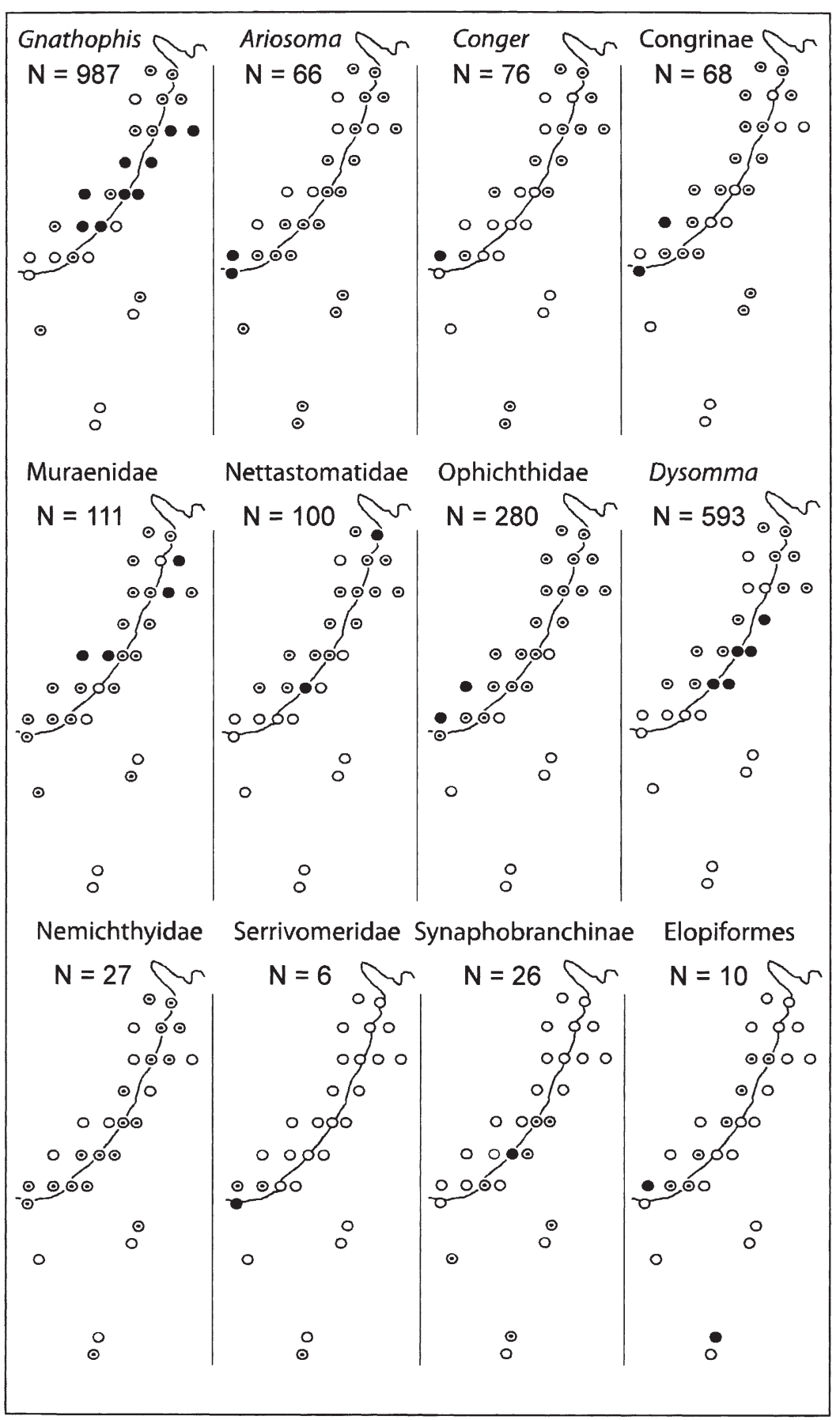

Fig. 5. Locations of stations where abundant taxa of leptocephali (see Table 1) were collected during the cruise. (०) Negative stations; (๑) positive stations; (•) stations where leptocephali $\leq 10 \mathrm{~mm}$ TL were collected. Line shows $200 \mathrm{~m}$ depth contour. Full specific names are given in Table 1

species of these families collected in the Kuroshio region during this study, but other than a few taxa such as $G$. nystromi nystromi, Dysomma anguillare, and Ophichthinae sp. 3, most taxa were not collected in large numbers.

The pattern of the collections made in offshore areas showing lower species richness and abundance of leptocephali of eel species that live on the shelf, has also been found in the western North Atlantic. The catch rates of shelf species were lower farther offshore in the Sargasso Sea (Miller \& McCleave 1994), as was species richness (Miller 1995). These studies suggested that a circulation cell near the shelf habitats of the northern Bahamas and frontal jets in the Subtropical Convergence Zone of the Sargasso Sea played a role in transporting the leptocephali of shelf eels into these offshore areas, but that they were much less abundant there than the leptocephali of oceanic eels such as Nemichthys scolopaceus and Serrivomer beanii.

In the Kuroshio region, the oceanic species were rare, with only a few leptocephali of the Nemichthidae and Serrivomeridae, and no specimens of the Derichthyidae being collected. However, these leptocephali are often quite abundant in offshore collections because they spawn in the open ocean (Castle 1970, Castonguay \& McCleave 1987a, Miller \& McCleave 1994, Wippelhauser et al. 1996). This suggests that either relatively few are transported from the open ocean into the Kuroshio Current, or that they primarily spawn during a different season.

\section{Spawning ecology}

This study provides support for the hypothesis that most species of shelf eels spawn close to their juvenile

cially of the families Ophichthidae, Congridae and Muraenidae. More than 120 species of these 3 families have been described from Japanese waters (Masuda et al. 1984, Nakabo 2000), and some of these species may live in the ECS. There were leptocephali of at least 33 and adult habitats in shallow water. Small leptocephali ( $\leq 10 \mathrm{~mm} \mathrm{TL}$ ) of at least 11 species were collected, and extensive spawning activity by at least 2 species was evident close to the shelf break in the western Kuroshio region. Gnathophis nystromi nystromi and 
Dysomma anguillare were clearly spawning near the shelf break in this area, because their leptocephali were rare in or absent from the southernmost transect and thus did not appear to be transported into the region from further south. The majority of the smallest leptocephali of these 2 species was collected within the Kuroshio Current at stations close to or outside the $200 \mathrm{~m}$ depth contour, or just over the shelf, but they were rare at or absent from the westernmost stations. This suggests that these species of eels may spawn at the edge of the current or close to the shelf break, rather than over the shallower water $<100 \mathrm{~m}$ farther onto the shelf. Other species of congrids also appeared to spawn near the southern Kuroshio region.

This type of evidence of spawning of marine eels is relatively rare, but other studies on leptocephali have indicated that most shelf eels appear to spawn close to their juvenile and adult habitats. Leptocephali and eggs of Gnathophis spp. have been collected over the shelf in New Zealand (Castle \& Roberson 1974), and small leptocephali of various taxa have been collected close to the coast of West Africa (Blache 1977). In the Sargasso Sea region of the western North Atlantic, the distribution of small leptocephali indicated that the spawning activity of most shelf eels was limited to areas in relatively close proximity to the islands of the Bahamas, but sampling did not occur up to or over shelf areas to verify the exact spawning location (Miller 1995). Support was however provided by the observation that relatively small leptocephali of Ariosoma balearicum were very abundant in the Providence Channel of the northern Bahamas, indicating that they had been spawned close to the banks (Miller 2002).

Other types of evidence indicate that various species of shelf eels may have a range of different spawning tactics and locations. Although adult moray eels and garden eels have been observed to spawn in shallow water with no apparent migration (Moyer \& Zaiser 1982, Thresher 1984, Ferraris 1985), Conger oceanicus, which dwells along the east coast of North America, appears to make a similar migration to that of Anguilla rostrata to spawn in the Sargasso Sea (McCleave \& Miller 1994). Other species may make shorter migrations, since ophichthid eels have been observed migrating over shallow waters, apparently to spawn in deeper waters (Cohen \& Dean 1970). However, the distribution of ophichthid leptocephali in the Sargasso Sea region strongly suggests they do not migrate very far offshore (Miller 1995), and this is supported by the collection of the smallest ophichthid leptocephali over the shelf in the Kuroshio region.

The wide range in size of the leptocephali of many species collected during this study indicated that their spawning seasons may be relatively long, as has been suggested by analyses of the otolith microstructure of Conger myriaster leptocephali that recruited to Korea (Lee \& Byun 1996). A relatively small leptocephali of $C$. myriaster was collected in November near the coast of eastern Japan (Mochioka et al. 1988), but there is little direct evidence about the spawning location or season of spawning of this or other species of marine eels in the region. The spawning season of many species of shelf eels may be more concentrated during the summer months, so it is possible that the sampling during this cruise occurred toward the end of the typical spawning season of some taxa.

\section{Distributional ecology in the Kuroshio region}

The patterns of distribution of the different taxa of leptocephali collected during this study suggested that some taxa such as the oceanic Nemichthyidae and Synaphobranchinae were transported into the region by the Kuroshio Current, that shelf species such as the Nettastomatidae, Ophichthidae and Elopiformes were originating from over the shelf, and that a few others showed clear evidence of spawning close to the shelf break. The evidence of spawning of shelf eels close to the shelf break and their overall distributions suggest that some of the leptocephali of these species may be retained over the shelf by eddies and that the Kuroshio Current may subsequently transport others to a variety of areas. The large-sized leptocephali of shelf eels collected in the WNP may have been recirculated from the northern Kuroshio by a southward countercurrent along the east side of the Ruykyu Islands (Nitani 1972), or transported toward the Kuroshio region from much farther east.

Leptocephali that become entrained into the Kuroshio Current would be transported to the north and then either to the northwest by the Tsushima Warm Current or to the northeast by the main part of the Kuroshio. The Tsushima Warm Current flows to the northwest toward Korea and then turns northeast and flows through the Tsushima Strait and into the Sea of Japan (Lie \& Cho 1994, Lie et al. 1998, Katoh et al. 2000). The northern Kuroshio parallels the east coast of Japan up to $33^{\circ} \mathrm{N}$, where it flows eastward away from Japan (Qiu et al. 1990, Hsueh et al. 1996, Qiu \& Miao 2000). There appears to be a large anticyclonic eddy at the eastern edge of the Tsushima Warm Current, just after it separates from the Kuroshio, that has been indicated by surface drifters (Lie \& Cho 1994) and infrared satellite images in the late fall and winter (Qiu et al. 1990, Sugimoto \& Tameishi 1992, Chen et al. 1992). This eddy could function to retain leptocephali from the edges of the western Kuroshio and Tsushima Currents in the area south of Japan, and other smaller 
eddies that occur along the edges of the currents could result in the retention of leptocephali within the ECS region. Therefore leptocephali spawned in the western Kuroshio Current could end up recruiting to a variety of areas including the ECS region, southern Japan, farther north along the east and west coasts of Japan, as well as the southern region of the Korean Peninsula.

More sampling for leptocephali throughout the region is needed to learn about the spawning ecology of eels in the ECS region and to examine the transport of their leptocephali by the Kuroshio and Tsushima Currents. Sampling during the summer season will be important in helping to gain a greater understanding of the spawning locations and seasonality of spawning of the various species of eels in the region.

Acknowledgements We thank the other members of the cruise who helped with the net sampling and plankton sorting and express our gratitude to the captain and crew of the RV 'Tansei Maru' for their assistance throughout the KT-00-16 cruise by the Ocean Research Institute of the University of Tokyo and for making the cruise a success despite the rough seas of the Kuroshio Current in November and December. Funding for M.J.M. was provided by the Japan Society for the Promotion of Science, and partial funding for this research was provided by grants from the Ministry of Education, Science and Culture of Japan (Grant-in-aid No. 08456094, 10460081, and 08041139), 'Research for the Future' Program No. JSPS-RFTF 97L00901 from the Japan Society for the Promotion of Science, Touwa Shokuhin Shinkoukai, and the Eel Research Foundation from Nobori-kai.

\section{LITERATURE CITED}

Aoyama J, Mochioka N, Otake T, Ishikawa S, Kawakami Y, Castle PHJ, Nishida M, Tsukamoto K (1999) Distribution and dispersal of anguillid leptocephali in the western Pacific Ocean revealed by molecular analysis. Mar Ecol Prog Ser 188:193-200

Arai T, Aoyama J, Ishikawa S, Miller MJ, Otake T, Inagaki T, Tsukamoto K (2001) Early life history of tropical Anguilla leptocephali in the western Pacific Ocean. Mar Biol 138:887-895

Blache J (1977) Leptocephales des poissons Anguilliformes dans la zone sud du Golfe de Guinée. Faune Trop ORSTOM 10:1-381

Böhlke EB (ed) (1989) Fishes of the western North Atlantic. Mem Sears Fdn Mar Res 1(9)

Castle PHJ (1965) Leptocephali of the Nemichthyidae, Serrivomeridae, Synaphobranchidae and Nettastomatidae in Australasian waters. Trans R Soc N Z Zool 5:131-146

Castle PHJ (1970) Distribution, larval growth, and metamorphosis of the eel Derichthys serpentinus Gill, 1884 (Pisces, Derichthyidae). Copeia 1970:444-452

Castle PHJ (1979) Early life-history of the eel Moringua edwardsi (Pisces, Moringuidae) in the western North Atlantic. Bull Mar Sci 29:1-18

Castle PHJ (1997) Garden eel leptocephali: characters, generic identification, distribution, and relationships. Bull Mar Sci 60:6-22

Castle PHJ, Robertson DA (1974) Early life history of the congrid eels Gnathophis habenatus and G. incognitus in New Zealand waters. N Z J Mar Freshw Res 8:95-110
Castonguay LD, McCleave JD (1987a) Distribution of leptocephali of the oceanic species Derichthys serpentinus and Nessorhamphus ingolfianus (family Derichthyidae) in the western Sargasso Sea in relation to physical oceanography. Bull Mar Sci 41:807-821

Castonguay M, McCleave JD (1987b) Vertical distributions, diel and ontogenetic vertical migrations and net avoidance of leptocephali of Anguilla and other common species in the Sargasso Sea. J Plankton Res 9:195-214

Chen C, Beardsley RC, Limeburner R (1992) The structure of the Kuroshio southwest of Kyushu: velocity, transport and potential vorticity fields. Deep-Sea Res 39:245-268

Cohen DM, Dean D (1970) Sexual maturity and migratory behaviour of the tropical eel, Ahlia egmontis. Nature 227: 189-190

Ferraris CJ (1985) Redescription and spawning behavior of the muraenid eel Gymnothorax herrei. Copeia 1985:518-520

Hsueh Y, Lie HJ, Ichikawa H (1996) On the branching of the Kuroshio west of Kyushu. J Geophys Res 101:3851-3857

Hwang C (1996) A study of the Kuroshio's seasonal variabilities using an altimetric-gravimetric geoid and TOPEX/POSEIDON altimeter data. J Geophys Res 101:6313-6335

Jespersen P (1942) Indopacific leptocephalids of the genus Anguilla: systematic and biological studies. Dana Rep 22: $1-127$

Kaneko A, Koterayama W, Honji H, Mizuno S, Kawatate K, Gordon RL (1990) Cross-stream survey of the upper $400 \mathrm{~m}$ of the Kuroshio by an ADCP on a towed fish. Deep-Sea Res 37:875-889

Katoh O, Morinaga K, Nakagawa N (2000) Current distributions in the southern East China Sea. J Geophys Res 105:8565-8573

Lee TW, Byun JS (1996) Microstructural growth in otoliths of conger eel (Conger myriaster) leptocephali during the metamorphic stage. Mar Biol 125:259-268

Lie H, Cho C (1994) On the origin of the Tsushima Warm Current. J Geophys Res 99:25081-25091

Lie H, Cho C, Lee J, Niiler P, Hu J (1998) Separation of the Kuroshio water and its penetration onto the continental shelf west of Kyushu. J Geophys Res 103:2963-2976

Lukas R, Firing ER, Hacker P, Richardson PL, Collins CA, Fine R, Gammon R (1991) Observations of the Mindanao Current during the western Equatorial Pacific Ocean Circulation Study. J Geophys Res 96:7089-7104

Masuda H, Amaoka K, Araga C, Uyeno T, Toshino T (eds) (1984) The fishes of the Japanese archipelago. Tokai University Press, Tokyo

McCleave JD (1993) Physical and behavioural controls on the oceanic distribution and migration of leptocephali. J Fish Biol 43(Suppl A):243-273

McCleave JD, Miller MJ (1994) Spawning of Conger oceanicus and Conger triporiceps (Congridae) in the Sargasso Sea and subsequent distribution of leptocephali. Environ Biol Fish 39:339-355

Miller MJ (1995) Species assemblages of leptocephali in the Sargasso Sea and Florida Current. Mar Ecol Prog Ser 121:11-26

Miller MJ (2002) Distribution and ecology of Ariosoma balearicum (Congridae) leptocephali in the western North Atlantic. Environ Biol Fish 63:235-252

Miller MJ, McCleave JD (1994) Species assemblages of leptocephali in the subtropical convergence zone of the Sargasso Sea. J Mar Res 52:743-772

Mochioka N, Kakuda S, Tabeta O (1982) Congrid leptocephali in the western North and Middle Pacific-I. Exterilium Ariosoma-type larvae. J Fac Appl Biol Sci Hiroshima Univ 21:35-66 
Mochioka N, Tabeta O, Kubota T (1988) A pre-leptocephalus larva of Conger myriaster (family Congridae) collected from Suruga Bay, central Japan. Jpn J Ichthyol 35: 184-188

Mochioka N, Tabeta O, Kakuda S, Tsukahara H (1991) Congrid leptocephali in the western north and middle Pacific. II. Non-exterilium Ariosoma type larvae. Bull Mar Sci 48: $606-622$

Moyer JT, Zaiser MJ (1982) Reproductive behavior of moray eels at Miyade-jima, Japan. Jpn J Ichthyol 28:466-468

Nakabo T (ed) (2000) Fishes of Japan with pictorial keys to species, 2nd edn. Tokai University Press, Tokyo (in Japanese)

Nitani H (1972) Beginning of the Kuroshio. In: Stommel H, Yoshida K (eds) Kuroshio: its physical aspects. University of Tokyo Press, Tokyo, p 129-163

Okamura O (1986) Fishes of the East China Sea and Yellow Sea. Contrib Seikai Reg Fish Res Lab 422 (in Japanese)

Qiu B, Miao W (2000) Kuroshio path variations south of Japan: bimodality as a self-sustained internal oscillation. J Phys Oceanogr 30:2124-2137

Qiu B, Toda T, Imasato N (1990) On Kuroshio front fluctuations in the East China Sea using satellite and in situ observational data. J Geophys Res 95:18191-18204

Schmidt J (1922) The breeding places of the eel. Phil Trans R Soc Lond B 211:179-208

Smith DG (1989a) Introduction to leptocephali. In: Böhlke EB

Editorial responsibility: Otto Kinne (Editor),

Oldendorf/Luhe, Germany (ed) Fishes of the western North Atlantic. Mem Sears Fdn Mar Res 1(9):657-668

Smith DG (1989b) Family Muraenidae: leptocephali. In: Böhlke EB (ed) Fishes of the western North Atlantic. Mem Sears Fdn Mar Res 1(9):900-916

Smith DG, Miller MJ (1996) Cyematid larvae of the Leptocephalus holti group in the Atlantic and Pacific Oceans (Pisces: Saccopharyngiformes). Breviora 503:1-12

Sugimoto T, Tameishi H (1992) Warm-core rings, streamers and their role on the fishing ground formation around Japan. Deep-Sea Res 39:S183-S201

Tabeta O, Mochioka N (1988) Leptocephali. In: Okiyama M (ed) An atlas of the early stage fishes in Japan. Tokai University Press, Tokyo, p 15-64 (in Japanese)

Thresher RE (1984) Reproduction in reef fishes. TFH Publications, Neptune City, NJ

Tsukamoto K (1992) Discovery of the spawning area for the Japanese eel. Nature 356:789-791

Tsukamoto K, Lee TW, Mochioka N (1998) Synchronized spawning of Anguilla japonica inferred from daily otolith increments in leptocephali. Ichthyol Res 45:187-193

Wippelhauser GS, Miller MJ, McCleave JD (1996) Evidence of spawning and the larval distribution of nemichthyid eels in the Sargasso Sea. Bull Mar Sci 59:298-309

Yuan Y, Takano K, Pan Z, Su J and 6 others (1994) The Kuroshio in the East China Sea and the currents east of the Ryukyu Islands during autumn 1991. La Mer 32:235-244

Submitted: June 7, 2001; Accepted: November 8, 2001 Proofs received from author(s): May 15, 2002 